\title{
DIRECT AND INDIRECT ILLOCUTIONARY SPEECH ACTS ON DONALD TRUMP'S VICTORY SPEECH IN 2016
}

\author{
Lanjar Mulyana ${ }^{1}$ \\ Engliana ${ }^{2}$ \\ English Education Department, Postgraduate Program, \\ Universitas Indraprasta PGRI \\ email: lanjarmulyana11@gmail.com ${ }^{1}$ \\ email: engliana@unindra.ac.id ${ }^{2}$
}

\begin{abstract}
This research analyzes direct and indirect illocutionary speech acts on Donald Trump's 2016 victory speech. This research is a qualitative descriptive study. This research focuses on utterances to analyze the types of illocutionary acts and how they are delivered in speech, directly or indirectly. The results of this study are: (1) there are five types of illocutionary speech acts found in the speech, namely commissive $24 \%$, directive $9.3 \%$, representative $17.3 \%$, expressive $24.6 \%$, and expressive $24.6 \%$ and declaration $22.7 \%$. The research findings show that the dominant illocutionary act is an expressive action that is $24.6 \%$. (2) Donald Trump delivers the speech that is mainly conveyed directly
\end{abstract}

Keywords: direct speech, indirect speech, illocutionary acts, speech, pragmatics.

\section{Introduction}

In everyday life, we are never separated from interactions with other people. As social creatures, everyone needs interaction to socialize with each other. In this case, everyone needs the same language in order to create good interactions. A good understanding of language will determine the smooth process of interaction. Everyone communicates with other people to give information to each other, convey ideas. Communication is essential in the role of the community. With communication, a harmonious social environment will be created. Communication is a process in which a person or several people, organizations, and communities create and use the information to connect with the environment and other people.

In general, communication is done verbally, which can be understood by both communicators. Suppose there is no verbal language that your partner can understand. In that case, communication can still be done using specific body movements, for example, smiling, shaking the head, and shrugging shoulders. This communication is known as the language of nonverbal communication. In the process of communication, of course, good mastery is needed among the communication actors.

This is intended so that the ideas or information in question can be appropriately conveyed and understood by the interlocutor. Without language, humans cannot convey their ideas. Therefore, language is an essential tool in human life. A person's language reflects his thoughts, the more skilled a person in language, the brighter and more evident the way of his thoughts. Skills can only be acquired and mastered by way of practice and lots of practice. Practicing language skills means practicing thinking skills. We also need to realize that the skills needed for effective speaking have a lot in common with those needed for effective communication to get a clearer picture. To convey an 
idea, one must be good at expressing it according to the context. Without adjusting to the context, it will be very vulnerable to misunderstanding. In this case, pragmatics is fundamental in the delivery of ideas according to context.

Pragmatics is the study of the use of language associated with the context of its use. The meaning of the language can be understood if the context is known. Pragmatic limits are rules for the use of language regarding forms and meanings associated with the intent of the speaker, context, and circumstances. When someone masters pragmatics, he can convey ideas or information well. Behind sounds, words, and sentences, there is an implied meaning that is very dependent on when, where, who is speaking, who is the interlocutor, and in what situations. In daily interactions, we sometimes have to convey something indirectly so that the other person is not offended by the intent that we convey. In this case, the application of pragmatics is needed so that the language conveyed becomes smoother.

Submission of information, ideas, or opinions must be conveyed in the best way. For example, an orator must have good language mastery and a good delivery method in a speech. Such ideas will be conveyed well and can be well received by the other person. Sometimes a speaker has to say something terrible, with a good delivery language will undoubtedly affect the acceptance of the intent by the other person. Austin first introduced the speech act in 1962. According to him, when people talk, people do not only speak but also take action. That statement is known as the birth speech act theory. Based on the explanation above, we know that speech acts are the basic language used to express meanings and express intention.

Usually, speech acts are sentences, but they can be words or phrases as long as it follows the rules needed to achieve intentions. Based on Austin, we recognize three types of speech acts: locutionary actions, illocutionary acts, and perlocutionary acts. The act is the same thing as speech, so we can also use the terms locutionary speech, illocutionary speech, and Perlocutionary speech. Searle (1980) states that a speaker can realize three types of actions pragmatically: locutionary act, illocutionary act, and perlocutionary act. This is in line with Austin's opinion, which divides the type of speech acts into locution, illocution, and perlocution.

Illocutionary acts can be conveyed through speech with communicative intentions. John Searle divides detailed classification of illocutionary actions. Illocutionary action consists of five main classes of speech acts, namely:

1) Representative speech acts that bind the speaker to the truth of what he says. This type of speech act is also called the assertive speech act. Included in this type of speech act are speech states, demands, acknowledges, shows, reports, give testimony, mentions, speculates.

2) The directive speech act is the speech act intended by the speaker so that the speech partner acts according to what is stated in the speech. The directive speech acts are also called impositive speech acts. Included in this type of speech acts include asking, inviting, coercing, suggesting, urging, ordering, charging, commanding, urging, pleading, challenging, giving cues.

3) This speech act is also called the evaluative speech act. Expressive speech acts are speech acts intended by the speaker. The speech is interpreted as an evaluation of the things mentioned in the speech, including speech to say thank you, complaint, congratulate, flatter, praise, blame and criticize.

4) Commissive speech acts are acts of speech that bind the speaker to carry out everything mentioned in his utterance, for example, swearing, promising, threatening, declaring ability, vowing.

5) Declaration speech acts are speech acts intended by the speaker to create new things (status, circumstances). Included in this type of speech are speeches intended to impress, decide, cancel, prohibit, grant, classify, lift, and forgive.

Speech is a greeting with a good arrangement to be conveyed to many people. Examples of speeches include state speeches, celebratory speeches, encouragement speeches, welcoming speeches for events or events. A good orator can give a positive impression to those who hear the speech. Public speaking skills can help to achieve a good career path. In making a speech, choose words 
carefully that are more elaborate, more explicit, more appropriate, more personal, and more encouraging.

Direct speech acts are speech acts that occur when speakers use sentences according to their intentions. For example, speakers use imperative sentences if the speaker intends to rule or invoke the other person. If a speaker wants to inform the other person, the speaker uses declarative sentences. If the speaker wants to ask the other person something, the speaker uses the sentence interrogative. What is meant by indirect speech acts is speech acts that occur if the speaker uses the speech intention, not by the speech intention, for example, declarative sentences that speakers usually use to inform something to partners, in speech used to order

The reasons for this study to analyze Trump's speech are due to his speeches often received highlights from social media, journalism, and news. Many considered the speeches are unique and controversial. The other reason is that his supporters and other American citizens truly welcomed his speech. For research purposes on speech acts, observe how well a speech can convince and assure an audience: what phrases occurred and how these phrases are used in the context.

\section{Method}

Researchers use two research methods in the social sciences, namely quantitative methods and qualitative methods. In this study, the writer used a qualitative method. This research is a qualitative descriptive study. This research focuses on utterances to analyze the types of illocutionary acts and how they are delivered in speech, directly or indirectly. Qualitative research is research that is descriptive and tends to use analysis. The process and meaning are given more attention in detail in qualitative research.

The theoretical foundation is used as the primary reference so that the focus of research is following the facts in the field. Besides, the theoretical foundation is also helpful to provide a general description of the research background and as a material discussion of research results. There is a fundamental difference between the role of the theoretical foundation in quantitative research with qualitative research. In quantitative research, research departs from theory to data. It ends in acceptance or rejection of the theory used. In contrast, in qualitative research, the researcher departs from the data, utilizes existing theories as explanatory material, and ends with a theory.

The technique of collecting data is implemented by doing several steps. The first step is that the writer downloads the scripts of Donald Trump's victory speech. Then, reads all the scripts every sentence in order to find out the Illocutionary Speech Acts utterances. Thus, several sentences reflect Illocutionary Speech Acts in each sentence. The second step is classifying the data source into some categories based on the theory of Illocutionary Speech Acts. For example, the dialog is in declaration, representatives or assertive, directives, expressive, or commissive. Then, the writer writes the data into paper sheets. After that, the writer gives a code to each datum to ensure that the data has been appropriately taken to analyze. In order to make it easier, the writer categorizes the code for each datum. The purpose was not to number the data but to make the writer easier to select and classify the data from the datasheet.

\section{Results and Discussion}

One of the characteristics of qualitative research is that the researcher has the right to be a research observer. Merriam states that one of the characteristics of all forms of qualitative research is that researchers are the main instrument for data collection and analysis. This means that researchers become the primary key in research, and the key instrument in this study is the researcher itself. There are two types of data cards used by the author in conducting this research. The first data card is a type of illocutionary speech act. The second one is the way the speech is conveyed, directly or indirectly. It will be explained by the findings below: 
a. Representative acts.

Representative acts that bind the speaker to the truth of what he says. This type of speech act is also called the assertive speech act. In this analysis, the writer found 13 data contains three claiming, three predicting, two describing, and five calling. Included in this type of speech act are speech states, demands, acknowledges, shows, reports, give testimony, mentions, speculates. Examples of these types of utterances are: "My sister is a smart student." The speech includes a representative speech act because it contains information whose speakers are bound by the truth of the speech content. The speaker is responsible that the utterance spoken is indeed a fact and can be proven in the field that his younger brother is diligent in learning and is a clever student in the class.

\section{"It is going to be a beautiful thing."}

This sentence can be categorized as representative of predicting. Donald Trump predicts that it is going to be a beautiful thing for their future. The sentence is delivered directly. Donald Trump directly explains what he predicts in the future.

\section{"Our veterans are incredible people."}

This utterance is categorized as representative of describing in the speech. Donald Trump described veterans' participation in his country. Donald Trump describes that his veterans in America have made a great effort to his country. The sentence describes directly in his speech.

\section{"We have a great economic plan."}

This utterance is classified as representative of describing. Donald Trump describes that his country has a great plan in the economy. The sentence is presently delivered in his speech. Donald Trump describes it directly in front of the people of America.

"And General Kellogg. We have over 200 generals and admirals that have endorsed our campaign. Furthermore, they're special people, and it's really an honor. We have 22 congressional Medal of Honor recipients. We have just tremendous people. A very special person who believed me and, you know, I'd read reports that I wasn't getting along with him. I never had a bad second with him. He's an unbelievable star. He is."

The utterance can be categorized as representative of claiming. Donald Trump claims that he has over 200 generals and admirals that have endorsed our campaign. It shows that his utterances, in this case, indicate representative of claiming. The utterance is conveyed directly during his speech. He tells the audience while he is delivering his speech.

\section{b. Directive acts}

The directive speech act is the speech act intended by the speaker so that the speech partner acts according to what is stated in the speech. Included in this type of speech acts include asking, inviting, coercing, suggesting, urging, requesting, charging, commanding, urging, persuading, giving cues. An example is "Please help me to do this task." This example belongs to the type of directive speech act because the speaker intended to take the appropriate action stated in his speech, which is to help do the task. The indicator of directive utterance is an action taken by the speech partner after hearing the utterance. In this analysis, the writer found seven expressions of requesting, persuading, and commanding. Here are the examples of the analysis. 
"To all Republicans and Democrats and independents across this nation, I say it is time for us to come together as one united people."

The sentence is categorized as the directive of asking or requesting. Trump asks all the American to come together as one united people. The words "it's time for us to..." show that the speech is classified as requesting something. Donald Trump delivers his speech directly and asks The United people to unite as one united people.

"We're going to dream of things for our country and beautiful things and successful things once again."

This utterance is categorized as a directive of persuading. The words "We are going to dream of things... and successful things once again" mean Trump is persuading his audience to do what he believes. Donald Trump conveys his speech directly to his people of America by persuading them to do something that he believes.

\section{"Say a few words. No, come on, say something."}

The utterance can be classified as a directive of commanding. Donald Trump asks Reince to say something in the middle of his speech. The utterance can be concluded that it is conveyed directly because Donald Trump said when he is on the stage, delivering his speech.

c. Expressive acts

Expressive speech acts are speech acts intended by the speaker. The speech is interpreted as an evaluation of the things mentioned in the speech, including speech to say thank you, complaint, congratulate, flatter, praise, blame and criticize. In this analysis, the writer found 20 expressions of thanking and apologizing. It will be explained by the examples below.

"Thank you. Thank you very much, everyone."

This sentence is categorized as expressive of thanking. The word thanks indicate a greeting from the president to the people of America. In this sentence, the expression of thanking is directly conveyed by Donald Trump.

\section{"Sorry to keep you waiting; complicated business; complicated."}

The utterance above belongs to the expression of apologizing from Donald Trump to the audience. It shows from the word "sorry" that the speaker expresses. The sentence is conveyed directly to the audience during the speech.

d. Commissive acts

It is acts of speech that bind the speaker to carry out everything mentioned in his utterance. In this analysis, the writer found 16 data of pledging and 2 data of vowing. Language has a dimension of content and context - dimensions of content (messages) and relationships. The message can be the same, but the meaning changes when the context changes. This change brings our understanding to various meanings, such as denotative meanings, connotative meanings, grammatical meanings, associative meanings, and other meanings. It believes that whoever becomes the president will deliver a promise, just like someone who will propose to his girlfriend. 
Then, after getting married, will the person care about the list of promises when the couple later realizes that their future is much better than just remembering those promises.

\section{"It's time. I pledge to every citizen of our land that I will be president for all Americans, and this is so important to me."}

The sentence can be classified as commissive of pledging. Donald Trump said, "I pledge to every citizen....", which shows that he promises something to his people during the speech. Donald Trump pledges it directly in front of the American people in his speech.

"Working together, we will begin the urgent task of rebuilding our nation and renewing the American dream."

This sentence is classified as a commissive of vowing. Donald Trump promises his people that he will work together to build the nation and renew the dream. Donald Trump conveys his speech directly to the people of America in his speech.

e. Declaration act

Declaration speech acts are speech acts intended by the speaker to create something new. Included in this type of speech are speeches intended to impress, decide, cancel, prohibit, grant, allow, classify, lift, forgive, and forgive. In this analysis, the writer found seven expressions of stating and declaring. It will be explained by the examples below.

\section{"I've just received a call from Secretary Clinton."}

In this speech, Trump tried to state to the people of America. It can be seen from the utterance above. It is categorized as declarative of stating. Donald Trump conveys the speech directly in front of his people.

"No dream is too big, no challenge is too great. Nothing we want for our future is beyond our reach. America will no longer settle for anything less than the best."

The utterance is categorized as declarative or declaring. It says that America has a big dream and believes that the people can reach the dream together under his leadership. They want to get into the best in the world. The utterance is conveyed indirectly. Donald Trump encourages the people of America to be the best in the world.

\section{Conclusion and Suggestions}

The writer has analyzed seventy-five (75) data from Donald Trump's Victory Speech in 2016 classified according to George Searle's theory of illocutionary acts. Based on the data analysis, two conclusions can be taken from this research. The writer concludes the results of this research as described below:

1. Based on Searle's theory, there are five classifications of illocutionary acts. From all the data that has been analyzed, the writer found results as described below:

a. The writer found thirteen (13) data, which is $17.3 \%$ data of representative acts. It indicates claiming ( 3 data), predicting (3data), describing ( 2 data), and calling (5 data).

b. The writer found seven (7) data, which is $9.3 \%$ data of directive acts. It indicates requesting (3 data), persuading (3 data), and commanding (1 datum).

c. The writer found eighteen (18) data, which is $24 \%$ data of commissive acts. It indicates pledging (16 data) and vowing (2 data). 


\section{INFERENCE: Journal of English Language Teaching}

Vol. 4, No. 1, April - July 2021

p-ISSN: 2615-8671

e-ISSN: 2615-868X

d. The writer found twenty (20) data, which is $24.6 \%$ data of expressive acts. It indicates apologizing (1 datum) and thanking (19 data).

e. The writer found seventeen (17) data, which is $22.7 \%$ data of declarative acts. It indicates stating (16 data) and declaring (1 datum).

From the data analysis above, the dominant illocutionary acts are expressive $(24.6 \%)$. It indicates that Donald Trump wants to say enormous thanks to the people of America for voting him as a president of The United States, and he wants to make America great again as his vision during the campaign.

2. From the data that has been analyzed, it can be concluded below:

a. The writer found seventy-two (72) data. It is conveyed directly during the victory speech.

b. The writer found three (3) data. It is conveyed indirectly during the victory speech.

In this Victory Speech in 2016, Donald Trump gives a speech briefly and clearly. President Donald Trump delivers thirty-one minutes Victory Speech. In his speech, most of Donald Trump's speech utterances are conveyed directly. In education, teachers can use pragmatics as a style of speaking, which helps them enrich their communication skills in dealing with students. By understanding basic knowledge of speech acts, teachers and students will

think critically to understand every conversation in their daily lives. To other researchers, especially to the researcher who wants to research a pragmatic approach, they can observe and explore more about speech acts theory.

\section{References}

Ramelan. (1991). Linguistics and its contributions to language teachers. Semarang: IKIP Semarang Press.w3

Richards. et al. (1992). The Longman Dictionary of Language Teaching and Applied Linguistics. . London: Pearson Education Limited.

Brown and Yule, G. (1983). Discourse Analysis. New York: Cambridge University Press.

Donald Trump's Victory Speech. (2016). Video, (Accessed July 2019). New York: https://www.youtube.com/watch?v=Qsvy10D5rtc

Donald Trump's Victory Speech Transcript. (Accessed July 2019). New York Time: https://www.nytimes.com/2016/11/10/us/politics/trump-speech-transcript.html

Foucault, M. (1972-1977). Power: Selected Interviews and Other Writings. New York: Pantheon Books.

Aitchison, J. et al. (2003). Thesaurus construction and use: a practical manual. London: Aslib IMI, The Association for Information Management, Staple Hall, Stone House Court.

Griffiths. (2006). The Strategy Factor in Successful Language Learning. Great Britain: Short Run Press Ltd.

Cutting, J. (2002). Pragmatics and Discourse: A Resource Book for Students. Great Britain: T.J. International Ltd.

Peccei, J. (1999). Pragmatics. London and New York: Routledge: Taylor and Francis Group.

Austin, J.L. (1962). How to Do Things with Words. Cambridge: Harvard University Press.

Kreidler, C. (2002). Introducing English Semantics. London: Routledge.

Searle, J. (1979). Expression and Meaning: Studies in The Theory of Speech Acts. United Kingdom: Cambridge University Press.

Yule, G. (1985). The Study of Language. United Kingdom: Cambridge University Press.

Vanderken, D \& Searle, J.R. (1985). Foundations of Illocutionary Logic. New York: Cambridge University Press.

Searle, J. R. et al. (1980). Speech Act Theory and Pragmatics. London:D Reidel Publishing Company. 
Wiratama, Y. (2017). Illocutionary Acts on Donald Trump Inaugural Speech. (Thesis). State Islamic University Syarif Hidayatullah, Jakarta.

Umar, T. (2016). The Analysis of Speech Act of President Joko Widodo at APEC Forum. (Thesis). Alauddin State Islamic University Makassar, Makassar.

Kroupa, J. (2017). Speech Acts in U.S. Presidential Candidate's Speeches. University of Pardubice, USA.

Vogtle, K.H. et al. (2010). Methods in Educational Research: From Theory to Practice. San Francisco: Jossey-Bass.

Kusumo, D. (2015). A Pragmatic Analysis of Illocutionary Acts in English Teaching-Learning Process at SMA N 1 WATES KULON PROGO. (Thesis). Yogyakarta State University, Yogyakarta.

Priatmoko, F.X. (2013). Critical Discourse of Susilo Bambang Yudhoyono's Speech. (Thesis). Dian Nuswantoro University, Semarang.

Moleong, L. J. (2008). Metode Penelitian Kualitatif. Bandung: Bandung Remaja Rosdakarya.

Huberman, A.M \& Miles, M.B. (1994). Qualitative Data Analysis. United Kingdom: Sage Publications. 